\title{
Characteristics of Canary Hair Sheep's Breed Carcass Fed Banana (Musa acuminate) By-Products: Effects on Regional Tissue Composition, pH and Color
}

\author{
Sydia Ahmed ${ }^{1}$, Victor Navarro ${ }^{1}$, Jose Raduan Jaber ${ }^{2}$, Esther San-Juan ${ }^{1}$, Eligia Ponce ${ }^{1}$ and Myriam R Ventura ${ }^{1^{*}}$ \\ ${ }^{1}$ Departamento de Patología Animal, Producción Animal, Bromatología y Tecnología de los Alimentos, Universidad de \\ Las Palmas de Gran Canaria, 35413, Arucas, Spain \\ ${ }^{2}$ Departamento de Morfologia, Campus de Arucas, Universidad de Las Palmas de Gran Canaria, 35413, Arucas, Spain \\ *For correspondence: Myriam.rodriguezventura@ulpgc.es \\ Received 06 April 2021; Accepted 17 June 2021; Published 18 September 2021
}

\begin{abstract}
The contributions of replacing rye-grass (Lolium spp.) hay with banana (Musa acuminata) by-products on carcass and tissue characteristics, $\mathrm{pH}$ and color, in the Canary hair sheep breed were studied. Twenty-two lambs with an initial live weight of $14.8 \pm 2.5 \mathrm{~kg}$ were individually housed and fed two different diets for 58 days: The first group (experimental diet) received as forage a mixture of fresh banana (Musa acuminata) by-products composed by leaves and pseudo-stem. The other one got commercial rye-grass (Lolium spp.) hay (conventional diet) as a fiber source. The two groups got an additional commercial concentrate food $(\mathrm{CON})$. After the 58 days growing trial $(24.3 \mathrm{~kg} \pm 1.0 \mathrm{~kg})$, seven lambs of each group (n=14) were slaughtered in the experimental slaughterhouse. The muscle, the $\mathrm{pH}$, and the color were measured at the time immediately after slaughter and $24 \mathrm{~h}$ later, using the muscles Longissimus thoracis et lumborum and semimembranosus. At that time (after $24 \mathrm{~h}$ ), the remaining semi-carcass was butchered and dissected for analysis of the carcass's regional and tissue composition. Although there is no significant difference on the tissue composition, carcass regional and the muscle $\mathrm{pH}$, there are significant differences in the color in the Longisimus toracis et lumborum between the two assessed diets. The incorporation of banana by-products in a diet to fatten lambs Canary hair sheep breed would not grossly alter the carcass quality, at least based on the assessed parameters. Banana by-products as a feeding resource can maintain animal productivity and meat quality. (C) 2021 Friends Science Publishers
\end{abstract}

Keywords: Banana by-products; Carcass traits; Hair sheep; Meat quality; Pelibuey sheep

\section{Introduction}

The potential use of non-conventional feeds (alternative feeds) in animal nutrition, in particular for the ruminant species, is being recommended by different international organizations in order to develop a more sustainable system of animal production (Ben Salem et al. 2008; Archimède et al. 2012). Conventional concentrate and forages are scarce, expensive, and irregular in arid and tropical areas. The cost of many traditional feeds is restricting their use in many countries, and producers are now turning to alternative feed sources (Blache et al. 2008).

A good approach to solve this problem is to find alternative feeds as local feeds and by-products, not used for the local human population, as a resource for animal nutrition (Ben Salem et al. 2008). However, animal health, animal production, and product quality should be preserved (Vasta et al. 2008).

Globally, 102 tonnes of banana was produced in 2010 to 116 million tons in 2019 , at an approximate value of 31 billion USD. Worldwide, the banana is one of the main fruits, after grapes, tomatoes, and apples (FAO 2020). It is cropped in tropic areas for its important relevance in the food sector and the bulk of banana cultivation is conducted informally by smallholder farmers. Bananas are mainly produced between twentieth parallels North $\left(20^{\circ} \mathrm{N}\right)$ and South $\left(20^{\circ} \mathrm{S}\right)$, cultivated in different climatic areas of the world. This fruit is mainly cultivated for human food, although almost $50 \%$ of this is not suitable but adequate for animal feeding (Ecocrop 2010; Archimède et al. 2012). Different by-products banana crops as leaves ( 5 to $10 \mathrm{~kg}$ per plant), pseudostems (25 to $50 \mathrm{~kg}$ per plant) and raceme stems ( 2 to $3 \mathrm{~kg}$ per plant), with 5-10 t dry matter per Ha of by-products production, is determined by the intensification of crops (Pieltain et al. 1999). Different parts of the fruit (peels) and the plant (leaves, stems, and stalks or pseudostems) are used in animal feeding as fresh plantain, ensiled and can be dehydrated, chopped, milled or cooked, to fed to livestock (Ecocrop 2010; Heuzé and Tran 2016). Dried banana leaves and pseudo stems have been used to

To cite this paper: Ahmed S, V Navarro, JR Jaber, E San-Juan, E Ponce, MR Ventura (2021). Characteristics of canary hair sheep's breed carcass fed banana (Musa acuminate) by-products: effects on regional tissue composition, $\mathrm{pH}$ and color. Intl J Agric Biol 26:431-435 
feed goats and sheep by (González-García et al. 2008; Marie-Magdeleine et al. 2009; Heuzé and Tran 2016; Barbera et al. 2018) achieving good results on intake and growth performance. Hence, the evidence of its nutritional value has been demonstrated in pigs and ruminants. However, little information is found regarding the effects of feeding with banana by-products (Musa acuminate) in characteristics and composition of sheep's breed carcass.

This paper aimed to study the outcomes of feeding with banana by-products (Musa acuminate) on the characteristics and composition of Canary Hair Sheep's breed carcass. The regional and tissue characteristics, the $\mathrm{pH}$ and the color of the carcass using Canary hair sheep breed lambs were analyzed. The Canary hair sheep breed is an original Canary meat sheep native of the Canary Islands (Spain), they are easily adaptable animals and are similar to other sheep breed spreading widely in tropical countries of America, Antilles and some African countries (called Pelibuey, Tabasco, West African sheep, Ovin Martinik sheep). This breed is directly associated with the intensive production of bananas and tomatoes being a basic element in the production cycle. The sheep consume the banana byproducts, both leftovers from production and packaging and also produce the manure necessary to maintain the fertility of the farmland. It is a fundamental element in the recovery of certain agricultural residues (Spanish Ministry of Agriculture, Fisheries and Food 2020).

\section{Materials and Methods}

\section{Animals and feeding supervision}

A total of 22 Canary hair sheep breed were collected. After weaning (mean weight $14.8 \pm 3.1 \mathrm{~kg}$ ), they were reared in individual pens and classified into two groups of eleven animals each (equilibrated based on body weight (BW). Lambs were individually fed ad libitum. After adapting the animals (10 days), they were dewormed and housed in individual corrals and fed for 58 days; each group received different forages. The first group (experimental diet) got a fodder comprised of $50 \%$ leaves and $50 \%$ pseudo-stem of banana by-products. The second group got commercial ryegrass (Lolium spp.) hay (conventional diet) as a fiber source. The groups got a supplement commercial concentrate feed (CON). The chemical compositions and ingredients are shown in Table 1; mineral blocks and water were ad libitum for all the lambs. By-products of banana were collected daily, chopped, and mixed on the experimental farms. Fodders were offered ad libitum. Fodder offered and rebuffs were weighed and noted daily in the two groups. The animals were fed for 58 days to reach slaughter weight (approximately $24 \mathrm{~kg} \mathrm{BW}$ ). The live weight of lambs was noted initially and at five days' intervals until slaughtered. Feed intake, daily gain and feed conversion ratio were determined in a recent study (Barbera et al. 2018). Finally, fourteen animals $(n=14)$ were randomly selected (seven lambs of each group) and slaughtered.

\section{Analytical methods of feedstuffs}

Analyses of the fodder provided (leaves and pseudostems of banana, commercial diets, and rye-grass) were calculated according to those described in AOAC (2003). In vitro digestibility of organic matter (IVOMD) was determined using the technique developed by Van Soest et al. (1966), following the modification by Ankom Technology Corporation, and digestible energy (DE) was estimated at 0.0185 x IVOMD (NRC 1988).

\section{Slaughter and carcass evaluations}

After 58 days growing trial, the slaughter weight was $24 \mathrm{~kg}$ $\pm 1.0 \mathrm{~kg}$ live body weight (LWT). The lambs were slaughtered in the experimental slaughterhouse available in the College of Veterinary Medicine of Las Palmas de Gran Canaria University.

\section{Carcass characteristics}

After the slaughter, bleeding, skinning, and evisceration of the carcasses were done and the carcass was located in a room at $5^{\circ} \mathrm{C}$, during $24 \mathrm{~h}$.

After $24 \mathrm{~h}$ slaughter, the carcasses were sagittally cut with an electric saw. Then, the left semi-carcass was butchered and left back to be dissected for the estimation of the carcass regional and tissue composition, following the methodology described by Colomer-Rocher et al. (1987).

After that, these carcasses were divided into five parts: cervical area, shoulder area, ribs (section between the $1^{\text {st }}$ and $12^{\text {th }}$ thoracic vertebrae), loin (section between the $1^{\text {st }}$ and $6^{\text {th }}$ lumbar vertebra) and leg (section between the last lumbar and the first sacral vertebra). The five cuts were weighed and added to obtain the weight of the cold half-carcass.

For tissue assessment, subcutaneous fat and intermuscular fat, muscles, bones, and other structures, such as lymph nodes, tendons, vessels, and nerves, were pulled apart and weighed individually to be expressed as a percentage relative to each cut.

The experiments described in this study meet requirements of the European Union Council (2010/63/EU) for animal experimentation.

\section{Meat quality: muscle $\mathbf{p H}$ and color parameters}

The muscle $\mathrm{pH}$ and the color were measured immediately after slaughter $\left(\mathrm{pH}_{0}, \mathrm{~L}_{0}\right.$, Chroma $\left._{0}, \mathrm{Hue}_{0}\right)$ and $24 \mathrm{~h}$ later $\left(\mathrm{pH}_{1}\right.$, $\mathrm{L}_{1}$, Chroma $_{1}, \mathrm{Hue}_{1}$ ) using the muscles Longissimus thoracis et lumborum and semimembranosus. The $\mathrm{pH}$ was performed with an electronic $\mathrm{pH}$-meter equipped with a combined $\mathrm{pH}$ surface electrode (Model MP 220, Mettler Toledo, USA), and the results were averaged and recorded. The meat color was measured in 5.0-cm-thick steaks between the $12^{\text {th }}$ and $13^{\text {th }}$ ribs using Minolta Model CR-300 chromameter. 


\section{Statistical study}

The information obtained from the carcass and meat quality traits were subjected to analysis of variance. Statistical analysis was based on mean comparison using the LSD test, with a minimum of $P<0.05$ for statistical significance (SAS 2000).

\section{Results}

\section{Carcass characteristics}

Parameters related to regional and tissue composition of the carcasses are summarized in Table 2. No statistical differences $(P<0.05)$ were observed on composition of the carcasses (shoulder, breast, leg, neck, ribs, and loin) and tissue composition (bone, muscle, and fat) between animals receiving banana by-products and conventional diets.

Total fat ranged from $10.2 \%$ on lambs fed banana byproducts to $10.8 \%$ from conventional diet; the subcutaneous fat contents (6.8 and 7.0\%) were similar in both groups, whereas the inter-muscle fat (3.1 and 3.9\%) and total fat $(10.2$ and $10.8 \%)$ percentage was higher in the conventional diet but not significantly different $(P<0.05)$.

\section{Meat quality: muscle $\mathrm{pH}$ and color parameters}

Regarding the meat quality, the muscle $\mathrm{pH}$ (Table 3) showed similar levels independently of the diet received $(P<0.05)$; the muscle $\mathrm{pH}$ for the two groups analyzed was in the range of 5.5 (average initial $\mathrm{pH}_{0}$ ) to 6.5 (average $\mathrm{pH} 24 \mathrm{~h}$ after slaughter $\mathrm{pH}_{1}$ ) in the Longissimus toracis et lumborum muscle, and in the semimembranosus muscle as well.

The meat color results (Table 3) showed that lightness (L*) was between 33.8 and 41.4; Chroma between 15.8 and 26.0 and Hue between 11.5 and 28.0 being higher on semimembranosus muscle $24 \mathrm{~h}$ after slaughter $\left(\mathrm{L}_{1} ;\right.$ Chroma $_{1} ;$ Hue $\left._{1}\right)$.

Nevertheless, the meat color (Table 3) was affected by the diet ingested but only showed a significant difference $(P$ $<0.05$ ) at the time of slaughter (Chroma 0 ; Hue ${ }_{0}$ ) and $24 \mathrm{~h}$ after slaughter (lightness $\mathrm{L}_{1}$; Chroma 1 ) in the Longissimus toracis et lumborum muscle, as semimembranosus muscle color did not show color differences Thus, luminosity coordinate $\left(\mathrm{Chroma}_{0}\right.$; lightness $\left.\mathrm{L}_{1} ; \mathrm{Chroma}_{1}\right)$ was lower in the banana by-products group compare to a conventional diet.

\section{Discussion}

The nutritive value of the experimental diet used in this study seems to be promising as forage for the livestock, as values shown in Table 1 determined by (Barbera et al. 2018) in a previous study and values found by GonzálezGarcía et al. (2008) and Pieltain et al. (1999).
Table 1: Ingredients, chemical composition and nutritive characteristics of the ingredients of the diets*

\begin{tabular}{lllll}
\hline & Banana diet & \multicolumn{2}{l}{ Conventional diet } \\
\hline Ingredients (\%) & & & \\
Rye-grass & 0 & 35 & \\
Banana pseudostems & 18 & 0 & \\
Banana leave & 18 & 0 & \\
Corn & 35 & 35 & \\
Barley & 14 & 15 & \\
Soybean meal & 10 & 10 & \\
Minerals premix & 0.5 & 0.5 & \\
& BBP & RGHAY & CON \\
Chemical composition & & & \\
Dry matter (DM, g/kg fresh weight) & 138 & 914 & 898 \\
Chemical composition of DM (g/kg DM) & & & \\
Crude Protein & 99.5 & 100 & 140 \\
Estimated digestible energy (MJ/kg DM) & 10.8 & 11.1 & 13.5 \\
\hline BBP: by-products banana plant; RGHAY: & Ray-Grass hay; CON: concentrate. * \\
Barbera et al. (2018) & & &
\end{tabular}

Table 2: Effect of the assessed diets on the carcass regional and tissue composition (\% weight semi-carcass)

\begin{tabular}{lllc}
\hline \% Weight (semi-carcass) & \multicolumn{3}{c}{ Type of diet } \\
\hline Shoulder & Banana by-products & Conventional & $P$ \\
Breast & $16.9 \pm 0.97$ & $17.1 \pm 1.14$ & NS \\
Leg (pelvic limb) & $10.4 \pm 1.20$ & $10.7 \pm 1.16$ & NS \\
Neck & $32.3 \pm 2.17$ & $32.9 \pm 2.02$ & NS \\
Anterior Ribs & $8.4 \pm 1.12$ & $8.0 \pm 1.35$ & NS \\
Ribs + Loin & $7.5 \pm 0.78$ & $7.3 \pm 1.13$ & NS \\
Bone & $19.0 \pm 0.76$ & $19.2 \pm 1.18$ & NS \\
Muscle & $24.8 \pm 3.45$ & $23.5 \pm 1.17$ & NS \\
Subcutaneous fat & $64.3 \pm 3.44$ & $65.2 \pm 1.94$ & NS \\
Inter-muscle fat & $7.0 \pm 3.49$ & $6.8 \pm 1.74$ & NS \\
Total fat & $3.1 \pm 4.59$ & $3.9 \pm 1.05$ & NS \\
Waste material & $10.2 \pm 3.80$ & $10.8 \pm 1.80$ & NS \\
\hline NS: No statistical significance $P<0.05$ & $0.69 \pm 0.14$ & NS \\
\hline
\end{tabular}

NS: No statistical significance $P<0.05$

Table 3: Effect of the assessed diets on the muscle $\mathrm{pH}$ and color

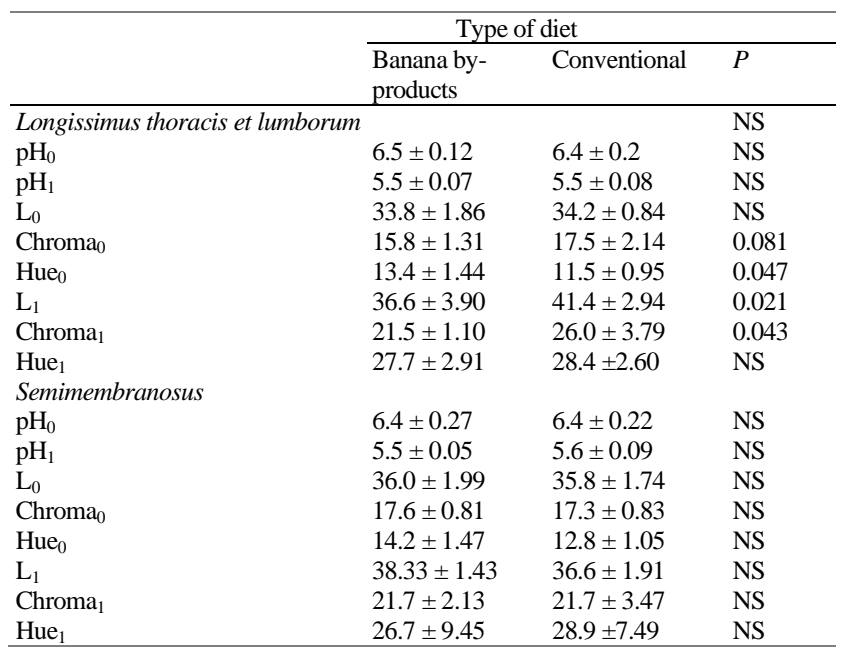

NS: Non statistical significant $P<0.05$

$\mathrm{pH}_{0}: \mathrm{pH}$ at the time of slaughter; $\mathrm{pH}_{1}: \mathrm{pH} 24 \mathrm{~h}$ after slaughter; $\mathrm{L}_{0}$ : lightness at the time of slaughter; Chroma o:at the time of slaughter; Hueo:at the time of slaughter; $\mathrm{L}_{1}$ : lightness $24 \mathrm{~h}$ after slaughter; Chroma1: after 24 of slaughter; Hue 1 after $24 \mathrm{~h}$ after slaughter

Means slaughter weight $(24.3 \pm 1.0 \mathrm{~kg})$ was gained in 58 days, reach in both cases in less time than the results described by Marie-Magdeleine et al. (2009) which Ovin Martinik sheep, where lambs spend 90 days to reach 22-24 $\mathrm{kg}$ feeding also with banana by-products. 
Values of slaughter and carcass weights were similar to values reported for tropical-sheep fed low-energy diets (Mahgoub et al. 2000; Santana-Andrade et al. 2017). Shoulder, breast, leg, neck, anterior ribs, and ribs + loin were not significantly affected by banana by-product based diet as compared to a conventional diet, whereas the percentage of shoulder weight on the carcass was lower than that described by Marie-Magdeleine et al. (2009) using similar experimental diet. Additionally, (Santana-Andrade et al. 2017) reported, with the similar breed and breeding conditions, a low percentage of the neck weight, a highs percentage of the shoulder weight and a similar percentage of the legs weight on the regional composition of the carcasses of Santa Ines hair sheep breed.

On the other hand, the animals belonging to the banana by-product-based diet did not show variations concerning fat content or other tissue characteristics in the back muscles compared to the conventional-diet group. Total fat ranged from $10.2 \%$ on lambs-fed banana byproducts to $10.8 \%$ from the conventional diet. Although animals feeding rye-grass hay on a conventional diet ingested a higher level of digestible energy (11.1 MJ/kg DE) compared with banana by-product groups $(10.8 \mathrm{MJ} / \mathrm{kg} \mathrm{DE})$, the subcutaneous fat contents $(6.8$ and $7.0 \%)$ were similar in both groups whereas the inter-muscle fat (3.1 and 3.9\%) and total fat $(10.2$ and $10.8 \%)$ percentage was higher in the conventional diet but not significantly different $(P<0.05)$. Despite all, it seems necessary to evaluate the fatty acid profiles in order to estimate the quality of the fat content in the carcass. Combellas (1982) studied the tissue composition for similar sheep breeds (West African) and similar slaughter weight $(24 \pm 1.0 \mathrm{~kg}$. $)$, reporting a lesser percentage of muscle tissue and bones but the higher fat content of the carcass. However, when the West African is raised in crossbreeding with more productive breeds like Dorset Horn, the tissue composition is similar to those observed by Combellas (1989).

Regarding the meat quality, the muscle pH (Table 3) showed similar levels independently of the diet received, not showing significant differences between different diets $(P<$ $0.05)$; the muscle $\mathrm{pH}$ for the different groups was in the range of 5.5 (initial $\mathrm{pH}_{0}$ ) to 6.5 ( $24 \mathrm{~h}$ after slaughter $\left.\mathrm{pH}_{1}\right)$ in the Longissimus toracis et lumborum muscle and in the semimembranosus muscle as well. These $\mathrm{pH}$ results were expected given the low difference in energy intake levels by both groups, as the lack of nourishment is the main reason for elevated $\mathrm{pH}$ in meats (Priolo et al. 2001).

Similar results were reported by (Al-Owaimer et al. 2008) that found that muscle $\mathrm{pH}$ was in the range of 5.6 to 5.7 of sheep fed Atriplex. Andrade et al. (2015) also reported an average of 6.24 initial $\mathrm{pH}\left(\mathrm{pH}_{0}\right)$ and an average of 5.5, $24 \mathrm{~h}$ after slaughter $\left(\mathrm{pH}_{1}\right)$ of the meat from Santa Inês hair breed lambs. The values found are normal and are indicative of meat quality, higher values can affect other characteristics such as color.

Nevertheless, the color of the meat of the lambs from this study can be considered light, as their lightness $\left(\mathrm{L}^{*}\right)$ was between 33.8 and 41.4 and lightness values for sheep are considered to vary from 30.0 to 49.5 (Leão et al. 2012). The meat color was affected by the diet ingested but only was significantly different $(P<0.05)$ in the Longissimus toracis et lumborum muscle, as semimembranosus did not show color differences. Otherwise, luminosity coordinate (Chroma 0 ; lightness $\mathrm{L}_{1}$; Chroma ${ }_{1}$ ) was lower in the banana by-products group, in agreement with other studies described by Morbidini et al. (2001) but opposite to results reported by Priolo et al. (2001), which found that meat from ruminants fed on pasture is darker than meat from animals fed concentrates. As an example, tannin-containing feeds produce opposite effects on meat, depending on the number of condensed tannins eaten by the sheep; meat color is paler when condensed tannins are showed in the diet (Vasta et al. 2008); further studies would be necessary to determine the condensed tannins contents on banana by-products.

\section{Conclusion}

The inclusion of banana by-products in a diet for growing Canary hair sheep breed lambs would not grossly alter the carcass quality, at least from the assessed parameters. Banana by-products as feed resources can preserve sheep productivity and meat quality. Nonetheless, diets supplemented with banana by-products should be carefully formulated, in order to guarantee to ruminants their nutritional requirements. Finally, it is important to emphasize that mixed-farming systems can improve the possibilities of better recycling of nutrients within systems, limiting expensive feeding inputs, and safeguarding the biodiversity of agricultural ecosystems by taking advantage of manure of the animals and by-products waste of crops.

\section{Acknowledgements}

Technical assistance and support of Dr. C. Gutierrez is gratefully acknowledged.

\section{Author contributions}

MRV designed the investigation, interpreted the results and wrote the manuscript. SA and VN carried out the growth trial and the analysis of the carcasses characteristics.SA, EP and ES performed the statistical analysis and analysed the data. JRJ helped performed analysis and co-wrote the paper.

\section{Conflicts of Interest}

All authors declare no conflicts of interest

\section{Data Availability}

The data generated during the current study are available from the corresponding author on reasonable request. 


\section{Ethics Approval}

The experiments described in this study meet requirements of the European Union Council (2010/63/EU) for animal experimentation.

\section{References}

Al-Owaimer AN, SM Zahra, BA Al-Bassam (2008). Effect of feeding with some atriplex species in complete diet on meat quality and carcass characteristics of najdi ram lambs. Intl J Agric Biol 10:105-108

AOAC (2003). Official Methods of Analysis, $17^{\text {th }}$ edn, $2^{\text {nd }}$ revision. Association of Official Analytical Chemists, Gaithersburg, Maryland, USA

Andrade ACS, FAFD Macedo, GRDA Santos, LDO Queiroz, NHAP Mora, TG Macedo (2017). Regional composition of carcass and tissue composition of cuts from lambs slaughtered with different subcutaneous fat thicknesses. Semin Ciênc Agrár Londr 38:2019-2028

Andrade ACS, GDDA Santos, FAFD Macedo, NHA Mora, RMGD Macedo, MG Torres (2015). Physicochemical and sensory traits of meat from Santa Inês lambs slaughtered with different subcutaneous fat thicknesses. Rev Bras Zootec 44:290-295

Archimède H, JL Gourdine, A Fanchone, R Tournebize, M Bassien-capsa, E González-García (2012). Integrating banana and ruminant production in the French West Indies. Trop Anim Health Prod 44:1289-1296

Barbera M, JR Jaber, S Ahmed-Salek, A Ravelo-Garci, E Rodríguez-Ponce, L Rey, MR Ventura (2018). Effects of replacing rye-grass (Lolium spp.) hay by Banana (Musa Acuminata L.) by-products on feed intake, growth, and feed conversion rate of canary hair sheep breed (pelibuey) lambs. Trop Anim Health Prod 50:8-13

Ben Salem H, A Priolo, P Morand-Fehr (2008). Shrubby vegetation and agro-industrial by-products as alternative feed resources for sheep and goats: Effects on digestion, performance and product quality. Anim Feed Sci Technol 147:1-2

Blache D, K Shane, B Maloney, K Dean, C Revell (2008). Use and limitations of alternative feed resources to sustain and improve reproductive performance in sheep and goats. Anim Feed Sci Technol 147:140-157

Colomer-Rocher F, P Morand-Fehr, A Kirton, R Delfa, I Sierra (1987). Método normalizado para el estudio de los caracteres cuantitativos y cualitativos de las canales caprinas y ovinas. Cuadernos INIA Spanish Ministry Agric 17:21-32

Combellas J (1989). A comparative study of growing and body composition of West African lambs and the crossbreeding West African x Dorset Horn. Doctoral Thesis. University of Cordoba, Spain

Combellas J (1982). Study of some growing and body composition characteristics of West-African lambs raised in an intensive nutrition system. Master Thesis. IAMZ, Zaragoza, Spain $\begin{array}{llll}\text { Ecocrop } & \text { (2010). } & \text { Ecocrop } & \text { database. }\end{array}$ http://ecocrop.fao.org/ecocrop/srv/en/home

FAO (2020). FAOSTAT statistics database, Agriculture, Rome, Italy (revised April 18 ${ }^{\text {th }}$ ). http://faostat3.fao.org/home/

González-García E, O Cáceres, H Archimède, J Arece, H Santana, R Delgado (2008). Nutritional assessment of banana (Musa paradisiaca) leaves and pseudostems for ruminants. In: ADSA-ASAS Joint Annual Meeting, Vol. 86, ASAS American Society of Animal Science, Champaign, Illinois, USA

Heuzé V, G Tran (2016). Banana (general). Feedipedia, a programme by INRA, CIRAD, AFZ and FAO. https://www.feedipedia.org/node/4670 Last updated on March 24, 2016, 12:17

Leão AG, AGS Sobrinho, GMB Moreno, HBA Souza, A Giampietro, RC Rossi, HL Perez (2012). Características físico-químicas e sensoriais da carne de cordeiros terminados com dietas contendo cana de açúcar ou silagem de milho e dois níveis de concentrado. Rev Bras Zootec 41:1253-1262

Mahgoub O, CD Lu, RJ Early (2000). Effects of dietary energy density on feed intake, body weight gain and carcass chemical composition of Omani growing lambs. Small Rumin Res 37:35-42

Marie-Magdeleine C, L Liméa, T Etienne, CH Lallo, H Archimède, G Alexandre (2009). The effects of replacing Dichantium hay with banana (Musa paradisiaca) leaves and pseudo-stem on carcass traits of Ovin Martinik sheep. Trop Anim Health Prod 41:1531-1538

Morbidini L, D Sarti, P Pollidori, A Valigi (2001). Carcass, meat and fat quality in Italian Merino derived lambs obtained with "organic" farming systems. In: Options Meditérranées Production Systems and Product Quality in Sheep and Goats, Vol. 46, pp:29-33, Rubino R, P Morand-Fehr (Eds). Zaragoza, Spain

NRC (1988). Nutrient requirements for dairy cattle, $6^{\text {th }}$ edn. National Academy Press, Washington DC, USA

Pieltain MC, JIR Castañon, MR Ventura, MP Flores (1999). The nutritive value of banana (Musa acuminata) by-products for ruminant. Anim Sci 69:213-216

Priolo A, D Micol, J Agabriel (2001). Effects of grass feeding systems on ruminant meat colour and flavour. A review. Anim Res 50:185-200

SAS (2000). In: SAS language guide for personal computers. Institute Inc., Cary, North Carolina, USA

Van Soest PJ, RH Wine, LA Moore (1966). Estimation of the true digestibility of forages by the in vitro digestion of cell walls. In: Proceedings $10^{\text {th }}$ International Grasslands Congress, pp:438-441. Helsinki, Finland

Spanish Ministry of Agriculture, Fisheries and Food (2020). "Raza Ovina Canaria de pelo" https://www.mapa.gob.es/es/ganaderia/temas/zootecnia/razas ganaderas/razas/catalogo/peligro-extincion/ovino/canariapelo/iframe-ejemplo-arca.aspx

Vasta V, A Nuddab, A Cannasb, M Lanzac, A Prioloc (2008). Alternative feed resources and their effects on the quality of meat and milk from small ruminants. Anim Feed Sci Technol 147: 223-147 